\title{
The Effect of Absorptive Capacity on Green Customer Capital under an Organizational Unlearning Context
}

\author{
Silvia Martelo-Landroguez ${ }^{1}{ }^{(1)}$, Gema Albort-Morant ${ }^{1,2}{ }^{\circledR}$, Antonio L. Leal-Rodríguez ${ }^{1, *}$ and \\ Belén Ribeiro-Soriano ${ }^{3}$ \\ 1 Departamento de Administración de Empresas y Marketing, Universidad de Sevilla, Av. Ramón y Cajal, 1, \\ 41018 Seville, Spain; smartelo@us.es (S.M.-L.); galbort@us.es (G.A.-M.) \\ 2 Departamento de Ciencias Sociales, Centro Universitario San Isidoro, C/Leonardo da Vinci, 17B, \\ 41092 Seville, Spain \\ 3 Kenan-Flagler Business School, University of North-Carolina, Chapel Hill, NC 27599, USA; \\ br6093@uncw.edu \\ * Correspondence: lealrodriguez@us.es; Tel.: +34-954-55-7567
}

Received: 31 October 2017; Accepted: 17 January 2018; Published: 20 January 2018

\begin{abstract}
Environmental management is becoming increasingly important within organizations and forms an essential part of their strategies. As customers are more concerned with the care of the environment, companies are required to be more aware of their actions. Consequently, companies must ignore their historical mindsets and assumptions to be able to adopt green-oriented practices and processes. Our specific research questions are: (i) How can firms become (more) green-oriented? and (ii) how can knowledge-based organizational capabilities drive this shift into greener companies, which may enhance green customer capital? The research model describes how the complementary roles of absorptive capacity (direct effect) and the fostering of an organizational unlearning context (moderating effect) affects green customer capital within the Spanish automotive component manufacturing sector. Empirical results reveal that to create green customer capital, companies should absorb new knowledge and build a context of organizational unlearning. In today's competitive environment, knowledge rapidly becomes obsolete, so companies need to encourage unlearning to make space for new knowledge that meets environmental needs and keeps pace with changing customer preferences. The research hypotheses were tested using partial least squares (PLS) path-modeling.
\end{abstract}

Keywords: absorptive capacity; green customer capital; organizational unlearning context; partial least squares

\section{Introduction}

The increasing number of international environmental regulations and growing environmental awareness among customers are two trends that are affecting businesses around the world. These trends are changing a firm's ability to achieve a competitive advantage [1,2]. Therefore, environmental management is becoming increasingly important within organizations and forms an essential part of their strategies. Companies must heed international environmental regulations and consumers' heightened environmental awareness, both of which inevitably affect rules and patterns of business competition [3-5]. Today, environmental management of businesses is fundamental [6-8].

Approximately 30 years ago, companies used to carry out strategies, activities, processes or routines that did not include the preservation or enhancement of the environment. Taking it into account, we can observe that companies have been working during a long time in an opposite way to the current one. The change in the present scenario means that companies assume the problems generated in the different interest groups and in the society in general. Therefore, companies are 
beginning to be interested in social and environmental problems which could be the result of the development of their activity. Therefore, companies must forget their way of acting through the unlearning of their business models and routines as well as by eliminating obsolete knowledge to give way to the new one.

The green perspective has emerged in response to the growing global problem of negative environmental impacts $[9,10]$. It is associated with numerous issues such as eco-friendly living, recycling, energy saving, waste management, and pollution reduction. To protect the environment, companies must adopt a preventive approach to environmental pollution. Environmental awareness is crucial nowadays because of the increasing number of international environmental regulations such as the Montreal Convention, Kyoto Protocol, Restriction of the Use of Certain Hazardous Substances (RoHS), and Waste of Electrical and Electronic Equipment (WEEE). Consequently, companies must adapt their strategies to prepare for the environmentalism era.

Although many companies still consider environmental management an unnecessary investment or even a burden that curbs their development and growth, more and more firms are taking an interest in protecting the environment. For instance, environmental management concepts such as green growth [10,11], green management [7,8], green marketing [12,13], green production [14], green absorptive capacity [15], green innovation [16-18], green intellectual capital [2,9], green supply chain management [19,20], green governance [21,22], green human resources [23], and among others are now widely used.

Nowadays, customer orientation is essential for company survival. Firms need to know how to handle relationships with customers by adding value [24,25]. Yet companies must also consider the environment because customers' decisions are conditioned by corporate actions in this area [3,4]. As well as having good relationships with customers, companies must acquire knowledge about their customers to build a strong reputation and respond more effectively to present and future customer needs $[9,26]$. Therefore, the acquisition of customer knowledge can lead to the development of successful new products and processes because this knowledge guides companies in the right direction [27].

We propose that it is not easy for companies that have spent their entire lives doing things in a certain manner to be seen as sustainable businesses by customers. In our opinion, that implies a series of changes. Therefore, the objective of this paper is to find what variables have to be taken into account by companies due to their influence on this behavioral change. We draw on studies that have cited organizational unlearning (OU) as a moderator variable [28]. We draw on other studies that have linked absorptive capacity (ACAP) to customer capital [29]. We also draw on studies that have focused on assessing the relationship between ACAP and different green concepts such as green innovation [30,31], green ACAP [15], and green information technology [32]. However, there is a scarcity of empirical works that have addressed the complementary roles of ACAP and the fostering of an OU context in the enhancement of green customer capital (GCC).

Hence, we aim to link absorptive capacity, green customer capital, and an organizational unlearning context in a same model within the environmental field. This research model is especially meaningful in the case of firms belonging to the automotive components manufacturing sector, which are characterized for having to work hard to satisfy their main customers, namely the main vehicles manufacturers by promoting high doses of flexibility in order to adapt to the environmental and technological requirements demanded by their customers. Accordingly, our specific research questions are: (i) How can firms become (more) green-oriented? and (ii) how can knowledge-based organizational capabilities drive this shift into greener companies, which may enhance green customer capital?

The green perspective underlying our analysis constitutes an innovative contribution to the existing literature. Therefore, this work could serve as reference to know the importance of create strong relationship within green supply chain management between suppliers and customers. This study is focused on the Spanish automotive component manufacturing sector (ACMS) due to suppliers and 
customers should work together to interfering impacts of the obsolete knowledge and, in this way, to respond to the potential changes of customers with regard to environmentalism.

Currently, European Union countries must comply with the mandatory requirements of the norms Euro3, Euro4 and Euro5 to assume the environmental challenge. These norms are a set of requisites that regulate the acceptable limits for the gas emission of internal combustion of the new vehicles sold in the Member states of the European Union. For this reason, companies of automotive sector encourage agreements with their suppliers-Spanish automotive component manufacturing sector-to commit in writing with their environmental policy and promote the efficient use of the automobile and the development of electric mobility. Therefore, the automotive sector will need to absorb new green knowledge (e.g., criteria of the ISO 14001, the REACH regulation, the elimination of dangerous substances, the management of a safe transportation and storage, and the use of recyclable packaging) to cope with radical changes. For this reason, Spanish automotive component manufacturing sector constitutes a suitable context for our study. The remainder of the paper is organized as follows. Section 2 reviews the conceptual framework and hypotheses that form the basis of the empirical analysis. Section 3 presents an empirical analysis building on information about 112 firms from the Spanish automotive component manufacturing sector. In Section 4, we present the results of the empirical study based on the analysis data. Finally, this study concludes with a discussion of the results, their implications, the limitations of the study, and suggestions for future research.

\section{Conceptual Framework and Hypotheses}

Green culture is the current environmentalist ideology that promotes the sustainable development of the economy and ecology supported by science, politics and aesthetics. More and more companies want to join this kind of movement or tendency. As customers are more concerned for the care of the environment, companies are required to be more aware of their activities. Several years ago, different companies, corporations and industries began to pay attention to this type of behavior and began to make changes within their culture to adopt this environmental responsibility of their actions. Such companies, corporations and industries became aware that this transformation in their behavior, would affect market behavior, and in turn it would imminently affect their sales; therefore, their profits would increase. This is how companies began to become "green companies". Some of them are driven by a sense of ecological conscience while others are driven by a sense of public image. Consequently, companies must ignore their historical mindsets and assumptions in order to be able to adopt green-oriented practices and processes.

In general, gaining a competitive advantage depends on tangible and intangible assets. It implies that organizations must have the right skills to manage external knowledge. This is known as absorptive capacity (ACAP) [31,33]. Research on knowledge management has often been limited to internal processes of knowledge. However, ACAP focuses on a firm's use of external knowledge [34,35]. ACAP has become an important topic in the business management research. Scholars $[36,37]$ have shown that a competitive advantage cannot be gained through internal knowledge alone; external knowledge is also necessary [37-41]. Moreover, exploiting external knowledge is a key component in the development of innovative capabilities [42]. Therefore, skills and capabilities such as ACAP are necessary to transmit and manage knowledge in all organizations because knowledge is a key resource for achieving a competitive advantage [37,43].

Intellectual capital, an intangible asset, is important too. Customer capital, in combination with human capital and structural capital, is one of the components of intellectual capital. Concretely, customer capital refers to the relationships between firms and customers and the value of these relationships $[26,44]$. In other words, it is the value inherent to the relationships that a firm builds and maintains with its customers, which may be reflected in the latter's loyalty to the company and/or its products or services. Because of the popularity of environmentalism, in our analysis we focused on a particular kind of customer capital that we label green customer capital (GCC) [45]. GCC refers to the value of customer relationships from a green perspective. The term GCC describes a firm's capability 
to understand customers' environmental wishes, problems, and behaviors [45]. It not only implies the building of social bounds but also the collection of information through this relationship between firms and customers. According to Wensley et al. [46], firms can use GCC to adapt strategies to meet customers' environmental needs.

Nowadays, being green is of paramount importance for organizations [1,9]. As previously discussed, companies must adjust to changes in the environment and consumer behavior. The relationship a company has with its customers is crucial for survival $[1,25,26]$. Consequently, organizations spend considerable time acquiring new knowledge about the environment, but they often use obsolete routines and procedures. Because knowledge becomes obsolete, fostering an organizational unlearning (OU) context is necessary to acquire new knowledge that is tailored to the environment [47]. According to Cegarra-Navarro et al. [48], we define an OU context as the deliberate framework or setting that favors the necessary conditions for the elimination of that obsolete knowledge. In fact, acquiring new knowledge and discarding useless knowledge are the keys to achieving a competitive advantage [49]. Unusable information and data could block the acquisition of new knowledge, hampering performance. Likewise, new external knowledge may interfere with old knowledge [50].

As previously stated, the green perspective offers a new way for companies to conduct their activities. Being green is a favorable way of promoting products or services while helping the environment and creating positive consumer awareness of the products or services on offer. By aligning themselves with the trends in consumers' environmental awareness and international environmental regulations, companies that engage in environmental management and green innovation are more productive, have better reputation, and are more competitive [1,5,51,52].

Environmental innovation may help firms reduce or eliminate the environmental burden of production processes [53]. In fact, the resource-based view explains how organizations achieve a competitive advantage through the proper use of their key resources and capabilities [54]. According to the resource-based view, environmental social responsibility can become a key capability that leads to sustainable competitive advantage [55]. Accordingly, companies must respond to the trends of consumer environmentalism and environmental regulations to improve competitiveness $[1,51,52]$.

\subsection{Absorptive Capacity and Green Customer Capital}

Gaining competitive advantage is based, not only on internal knowledge, but also on external knowledge [38,39]. Zahra and George [37] suggested that ACAP helps organizations achieve a competitive advantage by generating superior performance [56]. This competitive advantage owes to organizations' ability to acquire, assimilate, transform, and exploit external knowledge [37].

Another way to gain a competitive advantage is through customer management and relationships with customers [2,57]. Thus, as well as having good relationships with customers, companies must acquire knowledge about customers to forge a strong reputation and respond more effectively to current and future customer needs $[9,26]$. Firms with strong ACAP have better customer relationship management. ACAP is "the firm's ability to identify, assimilate, and exploit knowledge from the environment" [58] (pp. 569-570), which companies need to do to survive. Thus, ACAP is essential to gain a competitive advantage $[33,59]$.

ACAP also relates to innovation in firms. A company's innovativeness depends on the company's ability to recognize internal and external knowledge, assimilate it, and apply it. Accordingly, ACAP is an important characteristic for any firm that seeks to gain a competitive advantage $[43,60]$. ACAP allows firms to search for external knowledge in their environment, assimilate it, transform it, and exploit it [37]. Zahra and George [37] proposed the existence of two subsets of ACAP (i.e., potential and realized). While potential absorptive capacity (PACAP) refers to the ability of firms to acquire and assimilate external knowledge, realized absorptive capacity (RACAP) includes transformation and exploitation capabilities [61]. As previously discussed, external knowledge is necessary to improve organizational performance $[62,63]$. Today's dynamic environment means that customers' needs are 
constantly changing. Moreover, customers are becoming increasingly green-oriented, which influences the change in their needs. The technology required to meet those needs also changes rapidly, so organizations must continually search for opportunities [64].

We are in an era of customer orientation. The success of organizations consists of listening to the needs and desires of customers and meeting these needs and desires in the best way possible. Organizations aim to build relationships with customers to discover what they need at all times. This concern for the customer's needs has given rise to the term customer capital, which highlights the importance of customer relationship management [26]. Studies have generally focused on customer satisfaction, customer loyalty, and so forth $[65,66]$. This focus shows that customer orientation substantially affects the organization's ability to identify customer needs and that customer capital is essential for customer management [67-71]. The central values and key resources needed to achieve a competitive advantage have changed [26]. We are now in the era of knowledge and customer orientation. Intellectual capital plays an important role in achieving a competitive advantage and improves business value [9]. Hence, intellectual capital is one of the company's most valuable assets. Intellectual capital includes customer capital, which relates to the company's relationship with customers [72-74].

Long-term relationships with customers provide a platform for success in competitive markets [26]. Accordingly, customer capital encompasses the relationships between consumers and the entire organizational network (including the organization itself), the knowledge that these relationships generate, and the value of these relationships. These relationships play a key role in transforming intellectual capital into market value [72-74]. Crucially, customer capital allows organizations to obtain and develop knowledge regarding marketing channels and customer relationships [75]. Customer capital allows organizations to obtain information from relationships with customers, competitors, suppliers, trade associations, and the government [73].

The demographic, psychological, and socioeconomic profile of customers is constantly changing, influencing customers' behavior and preferences [46]. As these customer characteristics change, the organization's information regarding the customer profile may become obsolete, forcing the organization to use customer capital to create value [46,76]. One mechanism for minimizing the adverse effects of the automotive sector is the adoption of green innovations, including new technologies, management processes, and standards [1]. In fact, organizations should focus on how knowledge is used to adopt green processes or green administrative practices. As previously discussed, green innovations are not optional. Organizations must react to the trends of environmental management and customer satisfaction by building relationships. The concept of GCC has therefore emerged [45]. According to Albort-Morant et al. [45], GCC refers to the value derived from relationships between customers and organizations in response to the growing trends of strict international environmental regulations and consumer environmentalism.

Therefore, we propose the following hypothesis (see Figure 1).

Hypothesis 1 (H1). Absorptive capacity (ACAP) has a direct effect on green customer capital (GCC).

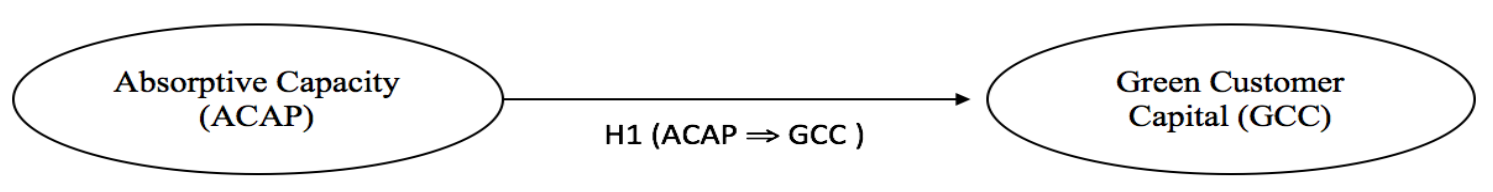

Figure 1. Model with direct effect.

\subsection{Organizational Unlearning as a Moderator of the Relationship between Absorptive Capacity and Green Customer Capital}

Achieving a competitive advantage is a primary objective for organizations, and scholars have developed numerous models that seek to explain knowledge management, skills, and abilities that 
organizations need to achieve a competitive advantage [50,77]. The environment is constantly changing, so organizations must unlearn their current knowledge to acquire, assimilate, transform, and exploit new external knowledge [37].

In line with Aledo-Ruiz et al. (2017) [78], the intricacy inherent to OU is the difficulty to measure it [79]. Once this drawback is recognized, the best approach to tackle this problem is by considering the notion of "organizational unlearning context". As posited by Azmi [80], an OU context can be rooted within the firm's structure by building and sustaining a corporate culture in which the firm's members deliberately attain new competencies and knowledge while they generate both the time and opportunity to assess and discover existing and new knowledge [78].

Hence, fostering an OU context allows firms to recognize and categorize inaccuracies, errors or partial truths that may be necessary to be disregarded or just ignored. For example, when individuals learn from their own mistakes and adjust their decision-making patterns accordingly, they are simply putting aside those inaccuracies or erroneous old patterns [77]. In this line, Cepeda-Carrión et al. [81] claim that replacing obsolete knowledge might be critical for those organizations that aspire to develop new products or services that entail new ideas, approaches or points of view. Consequently, an OU context might arrange the necessary basis for acquiring and producing new knowledge [82].

We therefore examined the effect of an OU context on an organization's ability to obtain and exploit external information and forget useless organizational routines. This ability improves the organization's customer relationship management to help the organization gain a competitive advantage (see Figure 2).

Organizational change is necessary for organizations to survive and prosper [83]. But changes lead to OU [76,77]. Continuous change requires modifications not only to work routines but also to social practices [84]. Organizational change entails getting employees to adopt new behaviors that benefit the company [85]. In fact, one of the essential organizational strategies to implement change is effective communication (i.e., good knowledge management). Companies must heed environmental changes and implement effective knowledge management to adapt rapidly to the turbulent, dynamic environment [84].

The term unlearning originated in cognitive psychology and learning in the 1950s [76]. Its use in business management, however, was scarce until relatively recently. When discussing unlearning, we must also discuss the learning process because unlearning is a determinant of organizational learning [86]. Nevertheless, OU does not always condition organizational learning. If learning does not affect organizational routines, $\mathrm{OU}$ is unnecessary [87].

To create a successful learning process, organizations must review, classify, and eliminate unnecessary knowledge. This is the paradox of success: Organizations must unlearn the ways of thinking and organizational routines that once generated profits but now hold the organization back by slowing the decision-making process [88]. There are numerous definitions of OU. For example, according to Tsang and Zahra [87], OU is the abandonment of knowledge or behavior without making a value judgment. We define the OU context as a framework that brings or enables the necessary conditions to unlearn and leave some space for new learning activities.

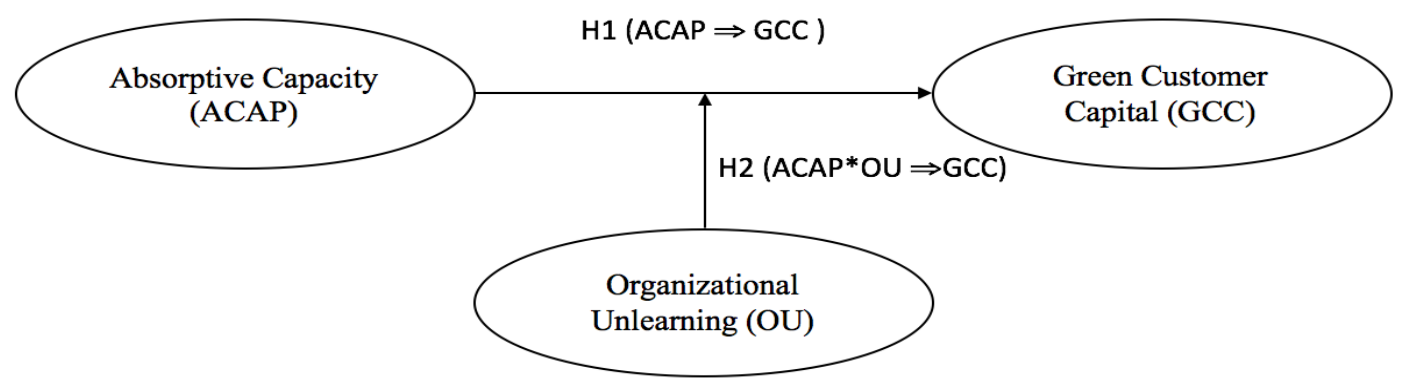

Figure 2. Model with moderator effect. 
From the literature, we identified several terms that are common to different definitions of OU. Such terms include abandonment, removal, and change of knowledge or organizational routines. We studied this concept in our analysis by testing the following hypothesis (see Figure 2).

Hypothesis 2 (H2). An organizational unlearning (OU) context positively moderates the relationship between absorptive capacity (ACAP) and green customer capital (GCC).

\section{Method}

\subsection{Sample and Measures}

We focus our study on the Spanish automotive component manufacturing sector (AMCS) because it stands as an innovative and knowledge-intensive industry. The Spanish automotive sector is considered a world referent, holding the second position among European car producers, behind Germany; and the eighth position worldwide. Hence, we understand this sector constitutes an interesting context to ground our analysis. In such scenario, companies shaping the auxiliary industry must work hard to satisfy their main customers, namely the main vehicles manufacturers-i.e., Ford, Renault, Mercedes, Nissan, Renault, Peugeot, Opel, Iveco, Seat, Citröen-located throughout the country and across its frontiers. Therefore, these clusters of manufacturers of equipment and components for the automotive industry are characterized by promoting high doses of flexibility to adapt to the environmental and technological requirements demanded by the automakers.

The sample was gathered from a list belonging to Sernauto (www.sernauto.es), the Spanish Association of Manufacturers of Equipment and Components for the Automotive Industry. Sernauto's associated companies comprise a set of more than $85 \%$ of the invoicing of the sector, congregating huge national and international groups, firms of capitalization and SMEs [89]. Of the 960 companies in the sector, 427 met the selection criteria. Specifically, these companies deployed project teams, used external knowledge extensively, and maintained strong relationships of interdependence in supply chains.

We ensured informants were professionally engaged, conscientious, and committed to providing accurate data by assuring the confidentiality of their responses. Phone calls were made to identify the CEOs and seek their assistance in distributing questionnaires to project team managers. Business academics with expertise in the subject area and senior project managers reviewed an early draft of the survey questionnaire. They provided feedback on clarity, comprehension, suitability, face validity, and readability of the scales and survey instructions. Informants who did not reply to the initial survey within three weeks were emailed a second set of survey materials. Data collection took place from September to November 2014.

The two mailing efforts yielded 112 usable surveys ( $25.7 \%$ response rate). The response rate was lower than expected, possibly because informants were overburdened by surveys. Nevertheless, the low response rate for this sample is a minor concern, since we performed two different nonresponse bias tests. We assessed potential nonresponse bias using $t$-tests that compared early responses to the initial mailing with late responses to the follow-up mailing, as well as between respondent and non-respondent firms in terms of their gender. For the first test (respond versus never respond), there was no significant difference between respondents and non-respondents in terms of gender. For the second test (early respondents/late respondents), there was not either significant difference between early and late respondents in terms of size. Hence, we can sustain that nonresponse bias is not a serious concern for our sample.

Our questionnaire consisted predominantly of scales from the literature. Respondents chose the best response from a seven-point Likert scale ranging from 1 ("I completely disagree") to 7 ("I completely agree"). Appendix A lists the questionnaire items. Jansen et al. [90] and Cepeda-Carrión et al. [91] validated and used the items for assessing ACAP, which consisted of two dimensions: potential absorptive capacity (PACAP) and realized absorptive capacity (RACAP). 
ACAP was measured using 21 items ( 9 for PACAP and 12 for RACAP). These items assessed the responding firms' ability to acquire, assimilate, transform, and exploit knowledge. Hence, we follow prior works like the ones developed by $[49,92]$, which model and measure ACAP as a multidimensional second-order construct. For GCC, we used the five items employed by Chen [9]. We adapted the measure for OU from Cegarra-Navarro and Sanchez-Polo [93], using the same three dimensions: examination of lens fitting (five items), consolidation of emergent understandings (six items), and framework for changing individual habits (seven items). The final scale had 18 items.

Whereas GCC was modeled as a reflective first-order construct, ACAP and OU were modeled as multidimensional constructs. We considered ACAP and OU to have superordinate form [94], which means that relationships flow from the construct to its dimensions. A superordinate construct represents a general concept that is manifested by its dimensions [95]. Each dimension exemplifies a different manifestation or realization of the underlying higher-order construct [94]. The measurement model had reflective first-order dimensions and a reflective second-order construct.

\subsection{Data Analysis}

Our research model, depicted in Figure 2, was tested using partial least squares (PLS), a variance-based structural equation modeling method. PLS simultaneously allows assessment of the reliability and validity of the measures of theoretical constructs and estimation of the relationships between these constructs [96]. We chose PLS for two reasons. First, we had a composite measurement model. Both theoretical studies [97-99] and empirical simulation studies [100,101] recommend and support the use of PLS for composite models. Second, as per Chin's [102] indications, we used PLS because we employed latent variable scores in subsequent analysis for modeling a second-order multidimensional construct, applying the higher-order component two-stage approach [103]. This modeling approach enables increased theoretical parsimony and lessens model complexity [104]. As mentioned above, this higher-order approach encompasses two stages: (i) the PLS algorithm is used to obtain the latent variable scores for the first-order constructs (i.e., PACAP and RACAP); which (ii) in the second stage, serve as manifest variables in the measurement of the second-order construct (i.e., ACAP). Thus, following Hair et al. [104] (p. 233) the second-order construct "is embedded in the nomological net in such a way that it allows other latent variables as predecessors to explain some of its variance, which may result in significant path relationships".

We selected Mode A for ACAP, OU, and GCC at both first- and second-order construct levels. Mode A uses correlation weights. That is recommended when estimating standardized regression coefficients in small to medium-sized samples and when dealing with indicators that are correlated [100]. Analysis was conducted in SmartPLS 3.2.6 [105].

\section{Results}

We analyzed and interpreted a PLS model in two phases. In the first phase, we assessed the reliability and validity of the measurement model (outer model). We thus specified the relationships between the observable variables and the underlying theoretical concepts. This analysis assessed the individual item reliability, construct reliability, average variance extracted (AVE), and discriminant validity of the indicators as measures of latent variables. In the second phase, we evaluated the structural model (inner model). We thus tested the extent to which the relationships or associations that were specified by the proposed model were consistent with the empirical data. Based on the results of this analysis, we drew conclusions regarding the relationships between constructs because their validity and reliability were guaranteed [106].

\subsection{Measurement Model}

Table 1 shows the results of reliability and validity assessment for each construct. The measurement model was completely satisfactory (see Tables 1 and 2). First, the indicators and dimensions were suitable because outer loadings were greater than 0.707 . Only some loadings were slightly below this 
critical level. We nonetheless retained these loadings to reinforce the content validity of the scale [106]. Second, all multidimensional constructs and dimensions met the requirements for construct reliability because their composite reliabilities were greater than 0.7. Third, the latent variables had convergent validity because their average variance extracted (AVE) measures were greater than 0.5 . Table 2 shows the results of discriminant validity testing using the heterotrait-monotrait ratio (HTMT). According to this criterion, all variables had discriminant validity because the values were less than 0.85 [107].

Table 1. Measurement model loadings, construct reliability, and convergent validity.

\begin{tabular}{|c|c|c|c|}
\hline Construct/Dimension/Indicator & Loadings & $\begin{array}{c}\text { Composite } \\
\text { Reliability (CR) }\end{array}$ & $\begin{array}{l}\text { Average Variance } \\
\text { Extracted (AVE) }\end{array}$ \\
\hline Absorptive capacity (ACAP) & & 0.972 & 0.946 \\
\hline Potential absorptive capacity (PACAP) & & 0.891 & 0.734 \\
\hline PACAP 1 & 0.858 & & \\
\hline PACAP 2 & 0.918 & & \\
\hline PACAP 3 & 0.855 & & \\
\hline PACAP 4 & 0.865 & & \\
\hline PACAP 5 & 0.825 & & \\
\hline PACAP 6 & 0.903 & & \\
\hline PACAP 7 & 0.771 & & \\
\hline PACAP 8 & 0.875 & & \\
\hline PACAP 9 & 0.832 & & \\
\hline Realized absorptive capacity (RACAP) & & 0.795 & 0.736 \\
\hline RACAP 1 & 0.763 & & \\
\hline RACAP 2 & 0.882 & & \\
\hline RACAP 3 & 0.892 & & \\
\hline RACAP 4 & 0.863 & & \\
\hline RACAP 5 & 0.866 & & \\
\hline RACAP 6 & 0.897 & & \\
\hline RACAP 7 & 0.843 & & \\
\hline RACAP 8 & 0.814 & & \\
\hline RACAP 9 & 0.912 & & \\
\hline RACAP 10 & 0.937 & & \\
\hline RACAP 11 & 0.840 & & \\
\hline RACAP 12 & 0.803 & & \\
\hline Green customer capital (GCC) & & 0.903 & 0.652 \\
\hline GCC 1 & 0.810 & & \\
\hline GCC 2 & 0.835 & & \\
\hline GCC 3 & 0.895 & & \\
\hline GCC 4 & 0.791 & & \\
\hline GCC 5 & 0.692 & & \\
\hline Organizational unlearning (OU) & & 0.966 & 0.905 \\
\hline Examination of lens fitting (ELF) & & 0.935 & 0.744 \\
\hline ELF 1 & 0.898 & & \\
\hline ELF 2 & 0.906 & & \\
\hline ELF 3 & 0.878 & & \\
\hline ELF 4 & 0.875 & & \\
\hline ELF 5 & 0.745 & & \\
\hline Consolidation of emergent understandings (CEU) & & 0.927 & 0.681 \\
\hline CEU 1 & 0.917 & & \\
\hline CEU 2 & 0.864 & & \\
\hline CEU 3 & 0.718 & & \\
\hline CEU 4 & 0.816 & & \\
\hline CEU 5 & 0.775 & & \\
\hline CEU 6 & 0.847 & & \\
\hline
\end{tabular}


Table 1. Cont.

\begin{tabular}{|c|c|c|c|}
\hline Construct/Dimension/Indicator & Loadings & $\begin{array}{c}\text { Composite } \\
\text { Reliability (CR) }\end{array}$ & $\begin{array}{l}\text { Average Variance } \\
\text { Extracted (AVE) }\end{array}$ \\
\hline Framework for changing individual habits (FCIH) & & 0.931 & 0.664 \\
\hline FCIH 1 & 0.783 & & \\
\hline FCIH 2 & 0.765 & & \\
\hline FCIH 3 & 0.599 & & \\
\hline FCIH 4 & 0.895 & & \\
\hline FCIH 5 & 0.817 & & \\
\hline FCIH 6 & 0.868 & & \\
\hline FCIH 7 & 0.932 & & \\
\hline
\end{tabular}

Table 2. Measurement model discriminant validity.

\begin{tabular}{cccc}
\hline & \multicolumn{3}{c}{ Heterotrait-Monotrait Ratio (HTMT) } \\
\hline Construct & ACAP & OU & GCC \\
\hline ACAP & & & \\
OU & 0.799 & & \\
GCC & 0.757 & 0.831 & \\
\hline
\end{tabular}

Note: $\mathrm{ACAP}=$ absorptive capacity; $\mathrm{GCC}=$ green customer capital; $\mathrm{OU}=$ organizational unlearning.

\subsection{Structural Model}

We assessed the structural model based on the sign, magnitude, and significance of the structural path coefficients and the adjusted coefficient of determination $\left(R^{2}\right)$. Table 3 shows the values for the variance explained $\left(R^{2}\right)$ in the dependent constructs and the path coefficients for the research model (Figure 3). Following Hair et al.'s [108], we used bootstrapping resampling (5000 resamples) to generate standard errors and t-statistics to evaluate statistical significance for the hypothesized relationships.

Table 3. Structural model results.

\begin{tabular}{|c|c|c|c|c|c|}
\hline \multicolumn{6}{|c|}{ Model A } \\
\hline \multicolumn{6}{|c|}{$R^{2}=0.623$} \\
\hline & Path Coefficient & t-Value & $p$-Value & 95\% BCCI & Support \\
\hline $\begin{array}{c}\text { Relationship } \\
\mathrm{H} 1: \mathrm{ACAP} \rightarrow \mathrm{GCC}\end{array}$ & $0.833^{* * *}$ & 6.134 & 0.000 & {$[0.547 ; 0.873]$} & Yes \\
\hline \multicolumn{6}{|c|}{ Model B } \\
\hline \multicolumn{6}{|c|}{$R^{2}=0.745$} \\
\hline & Path Coefficient & t-Value & $p$-Value & $95 \%$ BCCI & Support \\
\hline Relationship & & & & & \\
\hline $\mathrm{H} 1: \mathrm{ACAP} \rightarrow \mathrm{GCC}$ & 0.250 * & 1.863 & 0.026 & {$[0.057 ; 0.373]$} & Yes \\
\hline $\mathrm{H} 2: \mathrm{ACAP}^{*} \mathrm{OU} \rightarrow \mathrm{GCC}$ & $0.529^{* * *}$ & 4.107 & 0.000 & {$[0.447 ; 0.573]$} & Yes \\
\hline
\end{tabular}

Note: Bootstrapping 95\% bias-corrected confidence intervals (BCCI) in square brackets (based on $\mathrm{n}=5000$ subsamples). ${ }^{* * *} p<0.001 ;{ }^{* *} p<0.01 ;{ }^{*} p<0.05$ (based on $\mathrm{t}(4999)$, one-tailed test). $\mathrm{t}(0.05,4999)=1.645$; $\mathrm{t}(0.01,4999)=2.327 ; \mathrm{t}(0.001,4999)=3.092 . \mathrm{ns}=$ non-significant .

Model A (Table 3 and Figure 3) included only the two main direct links. In Model A, the direct relationship between ACAP and GCC was significant $(\mathrm{H} 1=0.833$; $\mathrm{t}$-value $=6.134)$. This significance was necessary but not sufficient to show that ACAP directly affected GCC with a moderating effect of OU (Model B). In addition, the analysis confirmed the moderating effect of OU on the relationship 
between ACAP and GCC. Hence, the direct influence of ACAP on GCC depended on the value of the moderating variable $\mathrm{OU}$.

Hypothesis 2 was tested using two-stage PLS approach to estimate moderating effects. According to Fassott et al. [109], if the independent and/or moderator variables are modeled as composites, the product-indicator technique is not advisable. In the first stage of the two-stage approach, a PLS path model comprising direct effects was run to calculate construct scores of the independent and moderator variables and save them for further moderation analysis. In the second stage, the interaction term $(\mathrm{ACAP} * \mathrm{OU})$ was built as the product of the construct scores of ACAP and OU. The interaction term and the latent variable scores of ACAP and OU were subsequently used as independent variables in a multiple regression on the latent variable scores of GCC. The coefficient of $A C A P * O U \rightarrow G C C$ was statistically significant $(\mathrm{H} 2=0.529$; $\mathrm{t}$-value $=4.107)$.

\section{A. Model with direct effect}

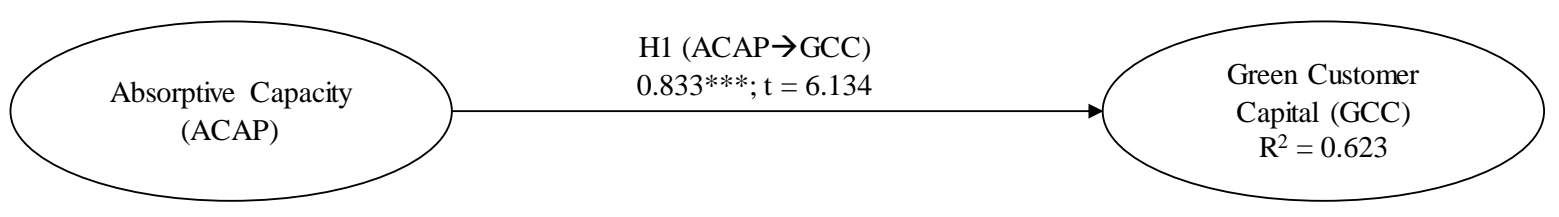

B. Model with moderator effect

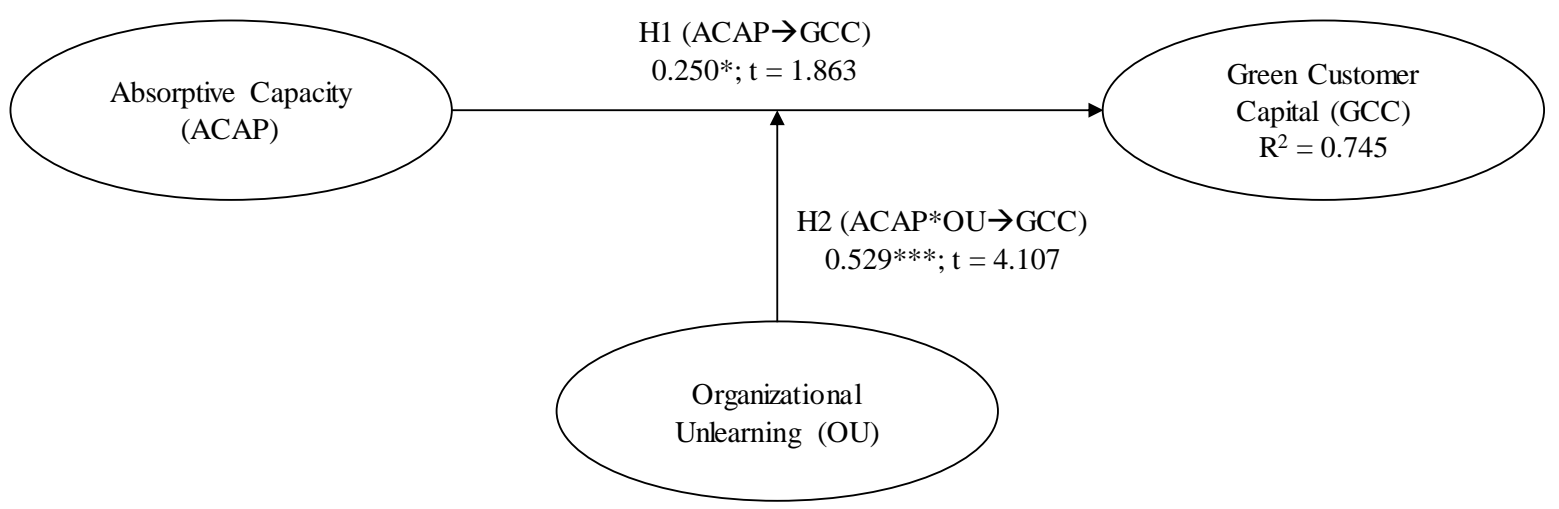

Figure 3. Summary of direct and moderator effects in Model A and Model B. Note: ${ }^{* * *} p<0.001$; ${ }^{* *} p<0.01 ;{ }^{*} p<0.05$ (based on $\mathrm{t}(4999)$, one-tailed test). $\mathrm{t}(0.05,4999)=1.645 ; \mathrm{t}(0.01,4999)=2.327$; $\mathrm{t}(0.001,4999)=3.092$. ns $=$ non-significant.

\section{Discussion}

\subsection{Theoretical Contribution}

A few years ago, environmental awareness was much lower. Nowadays, an increasing amount of companies is trying to become green. It implies that such companies have to change their processes and the way they have acted for a long time. Consequently, it denotes the need for an unlearning context so that the previous knowledge and the previous way of doing things do not block the new ones.

Obviously, companies want to reach those customers who are environmentally aware. Consequently, our goal is to help companies to face the changes needed in order to become green oriented, as it is what customers and the society demand today. To this end, we propose several constructs that must be taken into account if companies are to change because they will influence such change.

The increase in the number of international environmental regulations and growing customer environmentalism are shaping the businesses world [1,2]. Since environmental management is becoming increasingly important within organizations and forms an essential part of organizational 
strategies, companies are urged to ask whether what do they actually know about their stakeholders and how they currently operate is leading to success. Thus, our main contribution is the joint analysis of ACAP and the promotion of an OU context as complementary drivers of GCC.

GCC is the result of combining customer capital with a green approach [45]. GCC is defined as all relationships between consumers, organizations, and their networks where these relationships relate to green innovations or environmental management. Our research model links ACAP, GCC, and OU. This study is the first of its kind, since these three constructs had never before been analyzed together.

Our findings indicate that the promotion of an OU context positively moderates the relationship between ACAP and GCC. This suggests that firms need both learning and unlearning processes to adapt their strategies to meet customers' environmental needs. To survive, organizations must acquire and exploit new knowledge about the environment (i.e., ACAP), but they also need to renew obsolete knowledge, values, routines, and procedures (i.e., OU). Our study is the first empirical study to use GCC as a dependent variable.

Our findings corroborate $\mathrm{H} 1$ and $\mathrm{H} 2$ and provide empirical support for the predicted association between ACAP and GCC, implying that the two components of ACAP (i.e., PACAP and RACAP) play a pivotal role in determining GCC. This finding contributes to shed light and empirically validate Leal-Rodríguez et al. [33] and Larrañeta and Galan's [59] claim that both ACAP dimensions contribute to firm performance. This finding also supports Zailani and Rajagopal's [110] and Zhou and Benton's [111] proposition that good relationships with customers and effective information sharing with customers and suppliers are now crucial for enhancing performance. The effect of ACAP on GCC was observed to strengthen when OU was greater. Our confirmation of ACAP's positive effect on GCC enriches the theory on customer capital. These findings are consistent with Lambin's model of market-driven management, which posits that customer orientation is fundamental in mature markets characterized by a strong competition and an accelerated pace of technological innovation [112].

This study also shows that internal and external contextual factors are important for customer capital. Larrañeta and Galan [59], Leal-Rodríguez et al. [28], and Lane et al. [63] report that a similar degree of ACAP yields different performance depending on the context. Finding the context in which ACAP is most beneficial is crucial. Our study enriches the literature by examining whether the association between ACAP and GCC depends on the presence of an OU context. As predicted, the fostering of such OU context exerted a significant positive effect on the ACAP-GCC relationship. When OU was high, the effect of ACAP was amplified. This study contributes to our understanding of the role of $\mathrm{OU}$ in contingency theories in the context of customer relationships and GCC.

To sum up, this study offers three theoretical contributions. First, a new term, GCC, was introduced to the business literature, thus enriching the vast literature on customer capital. Second, this paper expands the literature on the field of knowledge management and customer capital, since the ties between ACAP, GCC, and OU were analyzed together for the first time. Finally, in the context of the automotive sector, the effects of these constructs and their linkages were identified. While this study is relevant to green businesses, its findings can nonetheless be extended to all companies because of the current green trend, whereby consumers are becoming more and more environmentally aware. Nowadays, every company needs to adapt to satisfy consumers' needs and provide value to increasingly environmentally conscious customers.

\subsection{Managerial Contribution}

To gain a competitive advantage, organizations shaping the Spanish automotive component manufacturing sector should let their employees regularly visit other units or project teams as well as external professionals such as advisers, managers, or consultants. In this way, organizations can thus improve their ability to acquire and assimilate knowledge required to comply with the demands of their main customers (i.e., large automakers). When employees do not visit other units or project teams or they are slow in recognizing market trends (competitors, laws, demographic changes, etc.), knowledge acquisition and assimilation capabilities are negatively affected. 
In addition, ACMS managers may become familiar with the ISO 14001 norm regarding systems of environmental management. This certification confirms the commitment of continuous improvement in relation to the management of the resources, waste, discharges and emissions of automaker companies. As part of the automaker's quality management system, an annual assessment of suppliers' service quality is frequently implemented. For instance, Toyota requests their suppliers to comply with certain ISO 14001 environmental criteria such as the removal of dangerous substances, the management of a safe transport and storage, and the use of recyclable packages, among others. Therefore, given that most automobile manufacturers comply with this certification, ACMS managers aiming to enhance their customer capital should also keep up to date regarding this issue. Namely, ACMS managers should be informed of the environmental requirements that are concretized in the firm's compliance with the ISO 14001 criteria.

Since our results reveal that an OU context moderates (reinforcing) the relationship between ACAP and GCC, ACAP seems to exert a greater effect on GCC in firms with higher levels of OU. According to the theory, an OU context lets firms learn more flexibly, allowing them to evolve rapidly and exploit new opportunities. Hence, fostering an unlearning context might lead to the promotion of such flexibility in supply chains, which can denote a potential source for improving firm efficiency and a significant measure of supply chain performance [113]. Besides, firms that promote an OU context and ACAP are less reluctant to take risks, so they are more agile and learn faster than other firms do. It allows them to capitalize on business opportunities. Such firms are also more proactive, which leads managers to engage in and commit themselves to new ideas, experimentation, and creative green processes. Proactiveness refers to seizing the initiative and taking opportunities to influence trends and potentially create demand [114]. Consequently, it implies acting as a leader, not a follower. The assumption underlying this idea is that, because of their strong OU capabilities, proactive firms are more flexible and open-minded in decision-making and are therefore more likely than competitors to be pioneering, innovative, and risk-taking.

\subsection{Limitations and Future Research}

Although this study contributes to the GCC literature, it has limitations. The sample comprised only Spanish automotive companies, so generalizing findings may be difficult. Future studies should examine multiple countries. Other factors such as firm size and type of ownership may be important control variables to include in the research model. The sample comprised manufacturers, but future studies should cover a broader range of industries, including the service industries, which may have different characteristics. This study used data from one respondent per firm, yet multiple responses per firm may be helpful. Future studies should examine data from respondents in different organizational levels or functions within the same firm. This study employed a cross-sectional design. A longitudinal study of how the ACAP and OU processes develop in firms would therefore be of interest.

\section{Conclusions}

In the Spanish automotive component manufacturing sector, organizations struggle to replace old knowledge with new knowledge. Employees should therefore improve their ability to recognize the value of substituting new external knowledge for existing knowledge to achieve a competitive advantage [37]. In terms of protecting the environment, ACMS companies need to promote stable cooperative relationships with their customers (i.e., vehicle manufacturers). Our results imply that relationships with stakeholders reinforce ACAP and are essential for achieving a competitive advantage.

In today's competitive environment, knowledge rapidly becomes obsolete, so companies need to strengthen their unlearning capabilities to acquire new knowledge that meets the needs of the environment as well as changes in consumer preferences. If managers are open to new ideas and ways of doing things, the OU process will be more effective, enhancing OU's moderating effect on the relationship between ACAP and GCC. Managers must not only be aware of OU's importance 
in gaining a competitive advantage, but also impress this importance upon other employees of the company to influence customer relationship management.

In sum, the automotive component manufacturing sector should work hard to absorb new knowledge that contributes to diminish the environmental effect of industrial action without sacrificing quality, cost, reliability, performance, or the efficient use of energy; while meeting ecological regulations, diminishing ecological harm, and leading to generally economic benefit [115]. In this way, automakers will continue to work with them in the design and development of new green vehicles [116].

Acknowledgments: This research is supported through the VI Plan Propio de Investigación de la Universidad de Sevilla 2017/000174.

Author Contributions: All authors were involved in the documentation phase, in choosing the research methodology, in data analysis, as well as in the results analysis and discussion. All authors participated in the manuscript preparation and have approved the submitted manuscript.

Conflicts of Interest: The authors declare no conflict of interest.

\section{Appendix A}

\section{Absorptive capacity}

Potential absorptive capacity (PACAP) $(1=$ completely disagree and $7=$ completely agree $)$ In my company:

- We have frequent interactions with top management to acquire new knowledge.

- Employees regularly visit other units or project teams.

- We collect information through informal means (e.g., lunches with colleagues, friends, and chats with partners).

- Members do not visit other units or project teams (reverse).

- We periodically organize special meetings with clients, suppliers, or third parties to acquire new knowledge.

- Members meet regularly with external professionals such as advisers, managers, or consultants.

- We are slow to recognize shifts in our market (competitors, laws, demographic changes, etc.) (reverse).

- New opportunities to serve our clients are quickly understood.

- We quickly analyze and interpret changing client demands.

Realized absorptive capacity (RACAP) $(1=$ completely disagree and $7=$ completely agree $)$ In my company:

- We regularly consider the consequences of changing market demands in terms of new ways to provide services.

- Employees record and store newly acquired knowledge for future reference.

- We quickly recognize the usefulness of new external knowledge for existing knowledge.

- Employees hardly share practical experiences (reverse).

- We laboriously grasp opportunities for our unit from new external knowledge (reverse).

- We periodically meet to discuss the consequences of market trends and new service development.

- It is clearly known how activities within our unit should be performed.

- Clients' complaints fall on deaf ears in our unit (reverse).

- We have a clear division of roles and responsibilities.

- We constantly consider how to better exploit knowledge.

- We have difficulties implementing new services (reverse).

- Employees have a common language regarding our services.

2. Green customer capital (GCC) $(1=$ completely disagree and $7=$ completely agree) 
- My firm designs its products or services in compliance with the environmental desires of its customers.

- My company's cooperative relationships about environmental protection with its upstream suppliers are stable.

- My company's cooperative relationships about environmental protection with its downstream clients or channels are stable.

- My company has stable and cooperative relationships regarding environmental protection with its strategic partners.

- The customer satisfaction regarding environmental protection of my company is better than that of its major competitors.

3. Organizational unlearning $(\mathrm{OU})$

Examination of lens fitting (ELF) $(1=$ completely disagree and $7=$ completely agree $)$ In my company:

- Employees are able to easily identify problems (new ways of doing things).

- Employees are able to identify mistakes by their colleagues.

- Employees are able to listen to the customer (e.g., complaints and suggestions).

- Employees are able to easily share information with managers.

- Employees try to reflect and learn from their own mistakes.

Consolidation of emergent understandings (CEU) ( 1 = completely disagree and 7 = completely agree) In my company:

- Managers seem to be open to new ideas and ways of doing things.

- Managers have tried to start projects.

- Managers recognize the value of acquiring, assimilating, and applying new information.

- Managers adopt employees' suggestions in the form of new routines and processes.

- Managers are willing to work together with employees of the company and resolve problems together.

- Managers are concerned that the way to respond to unforeseen circumstances should be known by all.

Framework for changing individual habits $(\mathrm{FCIH})(1=$ completely disagree and $7=$ completely agree $)$ In my company:

- The existence of new situations has helped individuals identify their own mistakes.

- The existence of new situations has helped individuals to undesirable attitudes.

- The existence of new situations has helped individuals identify behaviors that are improper for the place.

- Individuals recognize the forms of reasoning or to arrive at solutions such as inadequate.

- The existence of new situations has helped individuals change their behaviors.

- The existence of new situations has helped individuals change their attitudes.

- The existence of new situations has helped individuals change their thoughts.

\section{References}

1. Chen, Y.-S.; Shyh-Bao, L.; Chao-Tung, W. The Influence of Green Innovation Performance on Corporate Advantage in Taiwan. J. Bus. Ethics 2006, 67, 331-339. [CrossRef]

2. Chang, C.H.; Chen, Y.S. The determinants of green intellectual capital. Manag. Decis. 2012, 50, 74-94. [CrossRef]

3. Kang, S.; Hur, W.H. Investigating the antecedents of green brand equity: A sustainable development perspective. Corp. Soc. Responsib. Environ. Manag. 2012, 19, 306-316. [CrossRef] 
4. Martínez, P. Customer loyalty: Exploring its antecedents from a green marketing perspective. Int. J. Contemp. Hosp. Manag. 2015, 27, 896-917. [CrossRef]

5. Kong, T.; Feng, T.; Ye, C. Advanced Manufacturing Technologies and Green Innovation: The Role of Internal Environmental Collaboration. Sustainability 2016, 8, 1056. [CrossRef]

6. Russo, M.V.; Fouts, P.A. A Resource-Based Perspective on Corporate Environmental Performance and Profitability. Acad. Manag. J. 1997, 40, 534-559. [CrossRef]

7. Chen, C.C.; Shih, H.S.; Shyur, H.J.; Wu, K.S. A business strategy selection of green supply chain management via an analytic network process. Comput. Math. Appl. 2012, 64, 2544-2557. [CrossRef]

8. Martínez, F. Corporate strategy and the environment: Towards a four-dimensional compatibility model for fostering green management decisions. Corp. Gov. 2014, 14, 607-636. [CrossRef]

9. Chen, Y.S. The positive effect of green intellectual capital on competitive advantages of firms. J. Bus. Ethics 2008, 77, 271-286. [CrossRef]

10. Hou, J.; Chen, H.; Xu, J. External Knowledge Sourcing and Green Innovation Growth with Environmental and Energy Regulations: Evidence from Manufacturing in China. Sustainability 2017, 9, 342. [CrossRef]

11. Antal, M. Green goals and full employment: Are they compatible? Ecol. Econ. 2014, 107, 276-286. [CrossRef]

12. Cherian, J.; Jacob, J. Green marketing: A study of consumers' attitude towards environment friendly products. Asian Soc. Sci. 2012, 8, 117-126. [CrossRef]

13. Polonsky, M.J. Green Marketing Strategy: A Stakeholder Theory Approach. In Developments in Marketing Science; Proceedings of the 1995 World Marketing Congress; Springer International Publishing: Cham, Switzerland, 2015.

14. Baines, T.; Brown, S.; Benedettini, O.; Ball, P. Examining green production and its role within the competitive strategy of manufacturers. J. Ind. Eng. Manag. 2012, 5, 53-87. [CrossRef]

15. Chen, Y.-S.; Lin, Y.H.; Lin, C.Y.; Chang, C.W. Enhancing Green Absorptive Capacity, Green Dynamic Capacities and Green Service Innovation to Improve Firm Performance: An Analysis of Structural Equation Modeling (SEM). Sustainability 2015, 7, 15674-15692. [CrossRef]

16. Schiederig, T.; Tietze, F.; Herstatt, C. Green innovation in technology and innovation management-An exploratory literature review. RED Manag. 2012, 42, 180-192.

17. Albort-Morant, G.; Henseler, J.; Leal-Millán, A.; Cepeda-Carrión, G. Mapping the Field: A Bibliometric Analysis of Green Innovation. Sustainability 2017, 9, 1011. [CrossRef]

18. Aquilani, B.; Silvestri, C.; Ioppolo, G.; Ruggieri, A. The challenging transition to bio-economies: Towards a new framework integrating corporate sustainability and value co-creation. J. Clean. Prod. 2017, 172, 4001-4009. [CrossRef]

19. Chu, S.H.; Yang, H.; Lee, M.; Park, S. The Impact of Institutional Pressures on Green Supply Chain Management and Firm Performance: Top Management Roles and Social Capital. Sustainability 2017, 9, 764. [CrossRef]

20. Arbolino, R.; De Simone, L.; Carlucci, F.; Yigitcanlar, T.; Ioppolo, G. Towards a sustainable industrial ecology: Implementation of a novel approach in the performance evaluation of Italian regions. J. Clean. Prod. 2017, 178, 220-236. [CrossRef]

21. Ioppolo, G.; Cucurachi, S.; Salomone, R.; Saija, G.; Shi, L. Sustainable local development and environmental governance: A strategic planning experience. Sustainability 2016, 8, 180. [CrossRef]

22. Salvioni, D.M.; Gennari, F.; Bosetti, L. Sustainability and Convergence: The Future of Corporate Governance Systems? Sustainability 2016, 8, 1203. [CrossRef]

23. Renwick, D.W.; Redman, T.; Maguire, S. Green human resource management: A review and research agenda. Int. J. Manag. Rev. 2013, 15, 1-14. [CrossRef]

24. Hortinha, P.; Lages, C.; Lages, L.F. The Trade-Off between Customer and Technology Orientations: Impact on Innovation Capabilities and Export Performance. J. Int. Mark. 2011, 19, 36-58. [CrossRef]

25. Alteren, G.; Tudoran, A.A. Enhancing export performance: Betting on customer orientation, behavioral commitment, and communication. Int. Bus. Rev. 2016, 25, 370-381. [CrossRef]

26. Ling-Ching Chan, A.; Wang, W.Y. The causal relationships between aspects of customer capital. Ind. Manag. Data Syst. 2012, 112, 848-865. [CrossRef]

27. Scaringella, L.; Miles, R.E.; Truong, Y. Customers involvement and firm absorptive capacity in radical innovation: The case of technological spin-offs. Technol. Forecast. Soc. Chang. 2017, 120, 144-162. [CrossRef] 
28. Leal-Rodríguez, A.L.; Eldridge, S.; Roldán, J.L.; Leal-Millán, A.G.; Ortega-Gutiérrez, J. Organizational unlearning, innovation outcomes, and performance: The moderating effect of firm size. J. Bus. Res. 2015, 68, 803-809. [CrossRef]

29. Hsu, Y.H.; Fang, W. Intellectual capital and new product development performance: The mediating role of organizational learning capability. Technol. Forecast. Soc. Chang. 2009, 76, 664-677. [CrossRef]

30. Gluch, P.; Gustafsson, M.; Thuvander, L. An absorptive capacity model for green innovation and performance in the construction industry. Constr. Manag. Econ. 2009, 27, 451-464. [CrossRef]

31. Hashim, R.; Bock, A.J.; Cooper, S. The Relationship between Absorptive Capacity and Green Innovation. World Academy of Science, Engineering and Technology. Int. J. Soc. Behav. Educ. Econ. Bus. Ind. Eng. 2015, 9 , 1040-1047.

32. Cooper, V.A.; Molla, A. Absorptive capacity and contextual factors that influence green IT assimilation. Australas. J. Inf. Syst. 2014, 18, 271-288. [CrossRef]

33. Leal-Rodriguez, A.L.; Roldán, J.L.; Ariza-Montes, J.A.; Leal, A. From potential absorptive capacity to innovation outcomes in project teams: The conditional mediating role of the realized absorptive capacity in a relational learning context. Int. J. Proj. Manag. 2014, 32, 894-907. [CrossRef]

34. Lane, P.J.; Koka, B.R.; Pathak, S. The reification of absorptive capacity: A critical review and rejuvenation of the construct. Acad. Manag. Rev. 2006, 31, 833-863. [CrossRef]

35. Martelo-Landroguez, S.; Cegarra-Navarro, J.G. Linking knowledge corridors to customer value through knowledge processes. J. Knowl. Manag. 2014, 18, 342-365. [CrossRef]

36. Lane, P.J.; Lubatkin, M. Relative absorptive capacity and interorganizational learning. Strateg. Manag. J. 1998, 19, 461-477. [CrossRef]

37. Zahra, S.A.; George, G. Absorptive capacity: A review, reconceptualization, and extension. Acad. Manag. Rev. 2002, 27, 185-203.

38. Camisón, C.; Forés, B. Knowledge absorptive capacity: New insights for its conceptualization and measurement. J. Bus. Res. 2010, 63, 707-715. [CrossRef]

39. Gebauer, H.; Worch, H.; Truffer, B. Absorptive capacity, learning processes and combinative capabilities as determinants of strategic innovation. Eur. Manag. J. 2012, 30, 57-73. [CrossRef]

40. Bertrand, O.; Mol, M.J. The antecedents and innovation effects of domestic and offshore R\&D outsourcing: The contingent impact of cognitive distance and Absorptive Capacity. Strateg. Manag. J. 2013, 34, 751-760.

41. Srivastava, M.K.; Gnyawali, D.R.; Hatfield, D.E. Behavioral implications of absorptive capacity: The role of technological effort and technological capability in leveraging alliance network technological resources. Technol. Forecast. Soc. Chang. 2015, 92, 346-358. [CrossRef]

42. Cohen, W.M.; Levinthal, D.A. Absorptive capacity: A new perspective on learning and innovation. Admin. Sci. Q. 1990, 35, 128-152. [CrossRef]

43. Noblet, J.P.; Simon, E.; Parent, R. Absorptive capacity: A proposed operationalization. Knowl. Manag. Res. Pract. 2011, 9, 367-377. [CrossRef]

44. Leal-Millán, A.; Roldán, J.L.; Leal-Rodríguez, A.L.; Ortega-Gutiérrez, J. IT and relationship learning in networks as drivers of green innovation and customer capital: Evidence from the automobile sector. J. Knowl. Manag. 2016, 20, 444-464. [CrossRef]

45. Albort-Morant, G.; Martelo-Landroguez, S.; Leal-Rodriguez, A.L. Fostering a relationship learning context as a driver of green innovation performance and green customer capital. In Sustainability in Innovation and Entrepreneurship. Policies and Practices for a World with Finite Resources; Springer International Publishing: Cham, Switzerland, 2017.

46. Wensley, A.; Cegarra-Navarro, J.G.; Cepeda-Carrión, G.; Leal-Millán, A.G. How entrepreneurial actions transform customer capital through time: Exploring and exploiting knowledge in an open-mindedness context. Int. J. Manpow. 2011, 32, 132-150. [CrossRef]

47. Akgün, A.E.; Lynn, G.S.; Byrne, J.C. Antecedents and consequences of unlearning in new product development teams. J. Prod. Innov. Manag. 2006, 23, 73-88. [CrossRef]

48. Cegarra-Navarro, J.G.; Wensley, A.; Sanchez-Polo, M.T. An application of the hospital-in-the-home unlearning context. Soc. Work Health 2010, 49, 895-918. [CrossRef] [PubMed]

49. Cegarra-Navarro, J.G.; Cepeda-Carrión, G.; Wensley, A. Negative aspects of counter-Knowledge on absorptive capacity and human capital. J. Intellect. Cap. 2015, 16, 763-778. [CrossRef] 
50. Becker, K. Facilitating unlearning during implementation of new technology. J. Org. Chang. Manag. 2010, 23, 251-268. [CrossRef]

51. Shrivastava, P. Environmental Technologies and Competitive Advantage. Strateg. Manag. J. 1995, 16, $183-200$. [CrossRef]

52. Rondinelli, D.A.; Berry, M.A. Strategic and environmental management in the corporate value chain at Shaw Industries. Glob. Bus. Org. Excell. 1998, 17, 17-26. [CrossRef]

53. Markman, G.D.; Espina, M.I.; Phan, P.H. Patents as surrogates for inimitable and non-substitutable resources. J. Manag. 2004, 30, 529-544. [CrossRef]

54. Barney, J.B. Resource-based theories of competitive advantage: A ten-year retrospective on the resource-based view. J. Manag. 2001, 27, 643-650. [CrossRef]

55. Hart, S.L. A natural-resource-based view of the firm. Acad. Manag. Rev. 1995, 20, 986-1014.

56. Barney, J.B. Firm Resources and Sustained Competitive Advantage. J. Manag. 1991, 17, 99-120. [CrossRef]

57. Ingenbleek, P.; Dentoni, D. Learning from Stakeholder Pressure and Embeddedness: The Roles of Absorptive Capacity in the Corporate Social Responsibility of Dutch Agribusinesses. Sustainability 2016, 8, 1026. [CrossRef]

58. Cohen, W.M.; Levinthal, D.A. Innovation and Learning: The Two Faces of R \& D. Econ. J. 1989, 99, $569-596$.

59. Larrañeta, B.; Galan, J.L. Early Efforts to Develop Absorptive Capacity and Their Performance Implications. In Academy of Management Proceedings; Academy of Management: Philadelphia, PA, USA, 2014.

60. Gray, C. Absorptive capacity, knowledge management and innovation in entrepreneurial small firms. Int. J. Entrep. Behav. Res. 2006, 12, 345-360. [CrossRef]

61. Fosfuri, A.; Tribó, J.A. Exploring the determinants of potential absorptive capacity and its impact on innovation performance. Omega 2008, 36, 173-187. [CrossRef]

62. Isobe, T.; Makino, S.; Montgomery, D. Resource commitment, entry timing, and market performance of foreign direct investments in emerging economies: The case of Japanese international joint ventures in China. Acad. Manag. J. 2000, 43, 468-484. [CrossRef]

63. Lane, P.J.; Salk, J.; Marjorie, E.; Lyles, A. Absorptive capacity, learning, and performance in international joint ventures. Strateg. Manag. J. 2001, 22, 1139-1161. [CrossRef]

64. Ben-Oz, C.; Greve, H.R. Short-and long-term performance feedback and absorptive capacity. J. Manag. 2012, 41, 1827-1853. [CrossRef]

65. Chen, C.-N.; Ting, S.-C. A study using the grey system theory to evaluate the importance of various service quality factors. Int. J. Q. Reliab. Manag. 2002, 19, 838-861. [CrossRef]

66. Zeithaml, V.A.; Bitner, M.J.; Gremler, D.D. Services Marketing, 4th ed.; McGraw-Hill/Irwin: New York, NY, USA, 2005.

67. Menon, A.; Homburg, C.; Beutin, N. Understanding customer value in business-to-business relationships. J. Bus.-Bus. Mark. 2005, 12, 1-35. [CrossRef]

68. Athanassopoulou, P. Determining relationship quality in the development of business-to-business financial services. J. Bus.-Bus. Mark. 2006, 13, 87-116. [CrossRef]

69. Davis, D.F.; Golicic, S.L.; Marquardt, A.J. Branding a B2B service: Does a Brand differentiate a logistics service provider? Ind. Mark. Manag. 2008, 37, 218-227. [CrossRef]

70. Lee, G.J. Employee flow as an integrated and qualitative system: Impact on business-to-business service quality. J. Bus.-Bus. Mark. 2010, 17, 1-28. [CrossRef]

71. Powell, J.H.; Swart, J. Mapping the values in B2B relationships: A systemic, knowledge-based perspective. Ind. Mark. Manag. 2010, 39, 437-449. [CrossRef]

72. Edvinsson, L.; Malone, M.S. Intellectual Capital: Realizing Your Company's True Value by Finding Its Hidden Roots; HarperCollins: New York, NY, USA, 1997.

73. Bontis, N. Managing organisational knowledge by diagnosing intellectual capital: Framing and advancing the state of the field. Int. J. Technol. Manag. 1999, 18, 433-462. [CrossRef]

74. Van Buren, M.E. A yardstick for knowledge management. Train. Dev. 1999, 53, 71-78.

75. Bontis, N.; Chua Chong Keow, W.; Richardson, S. Intellectual capital and business performance in Malaysian industries. J. Intellect. Cap. 2000, 1, 85-100. [CrossRef]

76. Akgün, A.E.; Byrne, J.C.; Lynn, G.S.; Keskin, H. Organizational unlearning as changes in beliefs and routines in organizations. J. Org. Chang. Manag. 2007, 20, 794-812. [CrossRef] 
77. Zhao, Y.; Lu, Y.; Wang, X. Organizational unlearning and organizational relearning: A dynamic process of knowledge management. J. Knowl. Manag. 2013, 17, 902-912. [CrossRef]

78. Aledo-Ruiz, D.; Ortega-Gutiérrez, J.; Martínez-Caro, E.; Cegarra-Navarro, J.G. Linking an unlearning context with firm performance through human capital. Eur. Res. Manag. Bus. Econ. 2017, 23, 16-22. [CrossRef]

79. Howells, J.; Scholderer, J. Forget Unlearning?: How an empirically unwarranted concept from. Manag. Learn. 2015, 47, 443-463. [CrossRef]

80. Azmi, F.T. Mapping the learn-unlearn-relearn model: Imperatives for strategic management. Eur. Bus. Rev. 2008, 20, 240-259. [CrossRef]

81. Cepeda-Carrión, G.; Gabriel Cegarra-Navarro, J.; Leal-Millán, A.G. Finding the hospital-in-the-home units' innovativeness. Manag. Decis. 2012, 50, 1596-1617. [CrossRef]

82. Wang, X.; Lu, Y.; Zhao, Y.; Gong, S.; Li, B. Organisational unlearning, organisational flexibility and innovation capability: An empirical study of SMEs in China. Int. J. Technol. Manag. 2013, 61, 132-155. [CrossRef]

83. Carter, M.Z.; Armenakis, A.A.; Feild, H.S.; Mossholder, K.W. Transformational leadership, relationship quality, and employee performance during continuous incremental organizational change. J. Org. Behav. 2013, 34, 942-958. [CrossRef]

84. Cegarra-Navarro, J.G.; Martinez-Martinez, A.; Ortega Gutiérrez, J.; Leal-Rodríguez, A.L. Environmental knowledge, unlearning, and performance in hospitality companies. Manag. Decis. 2013, 51, 341-360. [CrossRef]

85. Van der Ven, N. The Shame of Reason in Organizational Change: A Levinassian Perspective; Bevan, D., Translator; Springer: Dordrecht, The Netherlands, 2011.

86. Huber, G.P. Organizational learning: The contributing processes and the literatures. Org. Sci. 1991, 2, 88-115. [CrossRef]

87. Tsang, E.W.; Zahra, S.A. Organizational unlearning. Hum. Relat. 2008, 61, 1435-1462. [CrossRef]

88. Audia, P.G.; Locke, E.A.; Smith, K.G. The paradox of success: An archival and a laboratory study of strategic persistence following radical environmental change. Acad. Manag. J. 2000, 43, 837-853. [CrossRef]

89. Sernauto. Annual Memory. 2015. Available online: http://www.sernauto.es/images/memorias_sernauto/ 2015/ (accessed on 22 September 2017).

90. Jansen, J.J.P.; Van Den Bosch, F.A.J.; Volberda, H.W. Managing potential and realized absorptive capacity: How do organizational antecedents matter? Acad. Manag. J. 2005, 48, 999-1016. [CrossRef]

91. Cepeda-Carrión, G.; Cegarra-Navarro, J.G.; Jimenez-Jimenez, D. The Effect of Absorptive Capacity on Innovativeness: Context and Information Systems Capability as Catalysts. Br. J. Manag. 2012, 23, 110-129. [CrossRef]

92. Cepeda-Carrion, I.; Leal-Millán, A.G.; Martelo-Landroguez, S.; Leal-Rodriguez, A.L. Absorptive capacity and value in the banking industry: A multiple mediation model. J. Bus. Res. 2016, 69, 1644-1650. [CrossRef]

93. Cegarra-Navarro, J.G.; Sanchez-Polo, M.T. Linking the individual forgetting context with customer capital from a seller's perspective. J. Oper. Res. Soc. 2008, 59, 1614-1623. [CrossRef]

94. Polites, G.L.; Roberts, N.; Thatcher, J. Conceptualizing models using multidimensional constructs: A review and guidelines for their use. Eur. J. Inf. Syst. 2012, 21, 22-48. [CrossRef]

95. Edwards, J.R. Multidimensional constructs in organizational behavior research: An integrative analytical framework. Org. Res. Methods 2001, 4, 144-192. [CrossRef]

96. Barroso, C.; Cepeda, G.; Roldán, J.L. Applying maximum likelihood and PLS on different sample sizes: Studies on SERVQUAL model. In Handbook of Partial Least Squares; Esposito Vinzi, V., Chin, W.W., Henseler, J., Wang, H., Eds.; Springer: Berlin, Germany, 2010; pp. 427-447.

97. Rigdon, E.E. Rethinking Partial Least Squares Path Modeling: In Praise of Simple Methods. Long Range Plan. 2012, 45, 341-358. [CrossRef]

98. Henseler, J.; Dijkstra, T.K.; Sarstedt, M.; Ringle, C.M.; Diamantopoulos, A.; Straub, D.W.; Ketchen, D.J.; Hair, J.F.; Hult, G.T.M.; Calantone, R.J. Common Beliefs and Reality About PLS: Comments on Ronkko and Evermann. Org. Res. Methods 2014, 17, 182-209. [CrossRef]

99. Rigdon, E.E. Choosing PLS path modeling as analytical method in European management research: A realist perspective. Eur. Manag. J. 2016, 34, 598-605. [CrossRef]

100. Becker, J.-M.; Rai, A.; Rigdon, E. Predictive validity and formative measurement in structural equation modeling: Embracing practical relevance. In Proceedings of the Thirty Fourth International Conference on Information Systems, Milan, Italy, 15-18 December 2013; pp. 1-19. 
101. Sarstedt, M.; Hair, J.F.; Ringle, C.M.; Thiele, K.O.; Gudergan, S.P. Estimation issues with PLS and CBSEM: Where the bias lies! J. Bus. Res. 2016, 69, 3998-4010. [CrossRef]

102. Chin, W.W. How to write up and report PLS analyses. In Handbook of Partial Least Squares; Esposito Vinzi, V., Chin, W.W., Henseler, J., Wang, H., Eds.; Springer: Berlin, Germany, 2010; pp. 655-690.

103. Wright, R.T.; Campbell, D.E.; Thatcher, J.B.; Roberts, N.H. Operationalizing multidimensional constructs in structural equation modeling: Recommendations for IS research. CAIS 2012, 30, 23.

104. Hair, J.F., Jr.; Hult, G.T.M.; Ringle, C.; Sarstedt, M. A Primer on Partial Least Squares Structural Equation Modeling (PLS-SEM); Sage Publications: Thousand Oaks, CA, USA, 2014.

105. Ringle, C.M.; Wende, S.; Becker, J.M. SmartPLS 3. SmartPLS GmbH: Boenningstedt. Available online: http:/ / www.smartpls.com (accessed on 18 April 2015).

106. Roldán, J.L.; Sánchez-Franco, M.J. Variance-based structural equation modelling: Guidelines for using partial least squares in information systems research. In Research Methodologies, Innovations and Philosophies in Software Systems Engineering and Information Systems; Mora, M., Gelman, O., Steenkamp, A.L., Raisinghani, M., Eds.; IGI Global: Hershey, PA, USA, 2012; pp. 193-221.

107. Kline, R.B. Principles and Practice of Structural Equation Modeling; The Guilford Press: New York, NY, USA, 2015.

108. Hair, J., Jr.; Sarstedt, M.; Hopkins, L.; Kuppelwieser, V. Partial least squares structural equation modeling (PLS-SEM) An emerging tool in business research. Eur. Bus. Rev. 2014, 26, 106-121. [CrossRef]

109. Fassott, G.; Henseler, J.; Coelho, P.S. Testing moderating effects in PLS path models with composite variables. Ind. Manag. Data Syst. 2013, 116, 1887-1900. [CrossRef]

110. Zailani, S.; Rajagopal, P. Supply chain integration and performance: US versus East Asian companies. Supply Chain Manag. 2005, 10, 379-393. [CrossRef]

111. Zhou, H.; Benton, W.C. Supply chain practice and information sharing. J. Oper. Manag. 2007, 25, 1348-1365. [CrossRef]

112. Lambin, J.J.; Chumpitaz, R.; Schuiling, I. Market-Driven Management: Strategic and Operational Marketing; Palgrave Macmillan: Basingstoke, UK, 2007.

113. Vickery, S.; Calantone, R.; Dröge, C. Supply chain flexibility: An empirical study. J. Supply Chain Manag. 1999, 35, 16-24. [CrossRef]

114. Jogaratnam, G.; Tse, E.C.; Olsen, M.D. An empirical analysis of entrepreneurship and performance in the restaurant industry. J. Hosp. Tour. Res. 1999, 23, 339-353. [CrossRef]

115. Srivastava, S.K. Green supply-chain management: A state-of-the-art literature review. Int. J. Manag. Rev. 2007, 9, 53-80. [CrossRef]

116. Leal-Rodríguez, A.L.; Ariza-Montes, A.J.; Morales-Fernández, E.; Albort-Morant, G. Green innovation, indeed a cornerstone in linking market requests and business performance. Evidence from the Spanish automotive components industry. Technol. Forecast. Soc. Chang. 2017. [CrossRef] 